\title{
Brucella ovis REO 198 natural and experimental infection in Santa Inês rams from Brazil
}

\author{
Infecção natural e experimental de Brucella ovis REO $198 \mathrm{em}$ \\ carneiros Santa Inês do Brazil
}

\author{
Cristiane Nakada Nozaki ${ }^{1}$; Hymerson Costa Azevedo ${ }^{2}$; \\ Nair Silva Cavalcanti de Lira ${ }^{1}$; Leandro Rodello ${ }^{1}$; Otávio Augusto Filho ${ }^{3}$; \\ Maurício Gauterio Dasso"; Sony Dimas Bicudo; \\ João Marcelo Azevedo de Paula Antunes ${ }^{1}$; Jane Megid ${ }^{5 *}$
}

\begin{abstract}
B. ovis pathogenicity was evaluated in experimentally inoculated and naturally infected rams. Ten animals were submitted to simultaneous conjunctival and intrapreputial inoculation with $2 \times 10^{9} \mathrm{CFU} /$ $\mathrm{mL}$ of B. ovis REO 198. After that, animals underwent physical examination and blood samples were collected for serology every week. Positive serology results started to be observed in the $3^{\text {rd }}$ week, with fluctuations in titers. Clinical changes began in the $5^{\text {th }}$ week after inoculation and were associated with positive serology in the acute phase of the disease. Presence of $B$. ovis in semen and urine culture was intermittent. Three non-inoculated animals showed natural infection. $B$. ovis was shed twice in semen of one serology-negative animal. The study underscored the pathogenic characteristics of $B$. ovis REO 198 in Santa Inês rams, as well as the importance of animals as potential sources of infection.
\end{abstract}

Key words: $B$. ovis, brucellosis, ovine, clinical signs, experimental inoculation

\section{Resumo}

Patogenicidade da $B$. ovis foi avaliada em carneiros inoculados experimentalmente e naturalmente infectados. Dez animais foram submetidos à inoculação conjuntival e intrapreputial simultânea com $2 \times 10^{9} \mathrm{UFC} / \mathrm{mL}$ de B. ovis REO 198. Depois disso, os animais foram submetidos ao exame físico e amostras de sangue foram coletadas para sorologia a cada semana. Sorologia positiva começou a ser observada na terceira semana, com flutuações nas titulações. As alterações clínicas começaram na quinta semana após a inoculação e foram associadas com sorologia positiva na fase aguda da doença. A presença de $B$. ovis em sêmen e cultura de urina foi intermitente. Três animais não inoculados apresentaram infecção natural. B. ovis foi eliminada duas vezes em sêmen de animal com sorologia negativa. O estudo destacou as características patogênicas de B. ovis REO 198 em carneiros Santa Inês, bem como a importância dos animais como potenciais fontes de infecção.

Palavras-chave: B. ovis, brucelose, ovinos, sinais clínicos, inoculação experimental

1 Discente(s), Faculdade de Medicina Veterinária e Zootecnia, FMVZ, Universidade Estadual Paulista, UNESP, Botucatu, SP. E-mail: crisnn@yahoo.com.br; naircl@hotmail.com; rodellovet@hotmail.com; joaomarceloantunes@live.com

2 Pesquisador, Empresa Brasileira de Pesquisa Agropecuária, EMBRAPA, Centro de Pesquisa Agropecuária dos Tabuleiros Costeiros, Aracaju, SE. E-mail: hymerson@cpatc.embrapa.br

3 Discente, Faculdade de Medicina Veterinária e Zootecnia, FMVZ, Universidade Estadual Paulista, UNESP, Botucatu, SP. E-mail: oafilho@hotmail.com

4 Fundação Estadual de Pesquisa Agropecuária, Instituto de Pesquisas Veterinárias Desidério Finamor, Laboratório de Brucelose, Eldorado do Sul, RS. E-mail: mgdasso@ipvdf.rs.gov.br

5 Profs. da FMVZ/UNESP, Botucatu, SP. E-mail: sony@fmvz.unesp.br; jane@fmvz.unesp.br

Author for correspondence 


\section{Introduction}

Brucella ovis is the etiological agent of ovine brucellosis (HOMSE; CASARO; CAMPERO, 1995), which is responsible for clinical or subclinical chronic disease, mainly characterized by epididymitis. The disease causes a subsequent decrease in fertility (BULGIN, 1990). It also leads to inflammatory processes in accessory sex glands and testicles, decreasing semen quality and making some animals become sterile. Effects on herd fertility will depend on the number of rams affected and on the severity of the lesions in infected animals. $B$. ovis has a special tropism for genital organs, causing epithelial hyperplasia and cyst formation. Interstitial inflammatory reaction may also lead to epididymitis, seminal vesiculitis, ampullitis, epididymal fibrosis, and to testicular atrophy and degeneration (PLANT; EAMENS; SEAMAN, 1986; WEST et al., 1993, PAOLICCHI et al., 2000). Epididymitis and low fertility due to decreased semen quality are the most important clinical manifestations in rams (NAREZ et al., 1999), and only $30 \%$ of the rams are affected by epididymitis. These animals become sources of infection due to the intermittent shedding of $B$. ovis in semen and urine (MANAZZA, 2005). The acute phase of the disease is characterized by decreased semen quality, as well as scrotal, epididymal or testicular acute inflammation and edema (RAMOS et al., 1966), whereas the chronic phase is characterized by testicular atrophy in variable degrees, and epididymal fibrosis and adherences (BLASCO, 1990b). Diagnosis of B. ovis infection is mainly based on a combination of clinical examination, isolation of the bacteria in infected animals (BLASCO, 1990a, b), and detection of antibodies anti-B. ovis in serum (ALTON et al., 1971). Researches on the pathogenicity of $B$. ovis were developed mainly in Merino and Corriedale breeds with B.ovis PA strain, then, the objective of the present study was to evaluate the pathogenicity of B. ovis REO 198 in naturally infected and experimentally inoculated Santa Inês rams from Brazil.

\section{Materials and Methods}

\section{Inoculums and challenge}

The Institutional Ethics and Animal Welfare Commission from the FMVZ/UNESP/Campus de Botucatu approved this study (ethics committee protocol $n^{\circ}$ : 69/2008). A lyophilized strain of $B$. ovis REO 198 (Instituto de Pesquisa Veterinária Desidério Finamor - IPVDF, Eldorado do Sul/RS, Brazil) was used for inoculation. 10 Santa Inês rams used in the experiment were acquired with 1-2 years olds of age, appeared healthy, randomly selected for experimental infection, and property known brucellosis-free flock. All animals were tested serologically negatives for Brucellosis by Agar gel immunodiffusion (AGID), and negatives for Polymerase Chain Reaction (PCR) (MANTEROLA et al., 2003) in urine/sperm samples. Rams were tested for the most relevant infectious diseases in sheep (visna-maedi, toxoplasmosis, leptospirosis), and resulted negatives. B. ovis suspension containing $2 \times 10^{9} \mathrm{CFU} / \mathrm{mL}$ was administered by intrapreputial route $(2 \mathrm{~mL})$ and by intraconjunctival route $(50 \mu \mathrm{L})$, simultaneously. The other five animals (control group) were treated with sterile saline solution, $2 \mathrm{~mL}$ by intrapreputial route and $50 \mu \mathrm{L}$ by intraconjunctival route, simultaneously. Blood, urine and semen samples were collected from all animals before they were treated. Blood samples were used in serological analyses, and semen and urine samples in culture and PCR for B. ovis. All samples collected before inoculation yielded negative results. After inoculation, blood, semen and urine samples were collected every week and submitted to the same analyses. Inoculated animals were kept in pastures in order to simulate natural breeding conditions of a sheep herd.

\section{Semen and urine collection}

Semen was collected from each animal by means of electroejaculation. Animals were prevented from breathing from 30 seconds to one minute. After that, spontaneous urination occurred and samples were colleted. 


\section{B. ovis culture and isolation}

Samples were cultured in modified ThayerMartin agar and Brucella blood agar, on the same day they were collected (BROWN; RANGER; KELLY, 1971). Plates were incubated at $10 \% \mathrm{CO}_{2}$, for approximately $3-7$ days, at $37^{\circ} \mathrm{C}$. The following tests were used in the identification of suspect colonies: Ziehl-Neelsen and Gram stains, positive urease and catalase, negative oxidase, absence of $\mathrm{H}_{2} \mathrm{~S}$ production, nitrate reduction, and growth in the presence of thionine and basic fuchsine (ALTON; JONES; PIETZ, 1976).

\section{Agar gel immunodiffusion test (AGID)}

Agar gel immunodiffusion was carried out with $B$. ovis bacterial cell wall antigen, produced by IPVDF. Gel was prepared according to the instructions of the Parana Institute of TechnologyTECPAR, using $1 \%$ agar in borate buffer. Reaction was carried out at $25^{\circ} \mathrm{C}$ in a dark chamber with positive and negative control sera, and results were read after 24, 48 and 72 hours.

\section{Results}

Figure 1 shows serological profile of the animals and development of clinical signs during the study. Antibody titers were detected by AGID in all animals in the third week after inoculation, decreasing soon after the $5^{\text {th }}$ week. After that, titers were variable. Positive results peaked from the $22^{\text {nd }}$ to the $23^{\text {rd }}$ week. Clinical signs in experimentally infected animals were mainly characterized by increased size and consistency, and hardening of the epididymis. Some animals showed testicular lesions or even unilateral epididymis atrophy. These changes became more frequent as time passed. They started in the $5^{\text {th }}$ week after inoculation, peaked between the $10^{\text {th }}$ and the $12^{\text {th }}$ week $(100 \%)$, and decreased soon after the $14^{\text {th }}(20 \%)$ week. A new peak was observed from the $16^{\text {th }}$ to the $20^{\text {th }}$ week (100\%), quickly decreasing after the $24^{\text {th }}$ week. After the $10^{\text {th }}$ week, clinical changes were observed in all rams, with testicular lesions in one animal $(10 \%$ of the population). After the $16^{\text {th }}$ week, sporadic cases of epididymis atrophy started to be observed. Natural infection was observed in three $(60 \%)$ of five control animals. These rams were infected by means of occasional contact between the control and the experimental group. Infected control animals showed increase in epididymis size and consistency, as well as increase in testicle size. Theses changes started two months after experimental animals were inoculated and ended six months after inoculation. Only two animals were positive in serology, at 30 days and four months. However, B. ovis shedding in semen was observed twice in an animal negative in serology, at four and six months.

Intermittent shedding of the microorganism in semen was observed in eight animals (80\%), mainly from three to seven months after inoculation. Five (50\%) animals shed B. ovis only once, beginning at three and ending at seven months. Two (20\%) animals shed it twice, between four and seven months, and one (10\%) animal shed it three times, between four and seven months. B. ovis was observed in urine samples of seven animals (70\%), between 15 days and eight months after inoculation. Three (30\%) animals shed the microorganism only once, beginning at 15 days after inoculation and lasting for four months. Four (40\%) animals shed the organism twice, between 15 days and eight months. 
Figure 1. Number of positive animals associated with the number of animals showing clinical alterations in rams experimentally inoculated with B ovis REO 198.

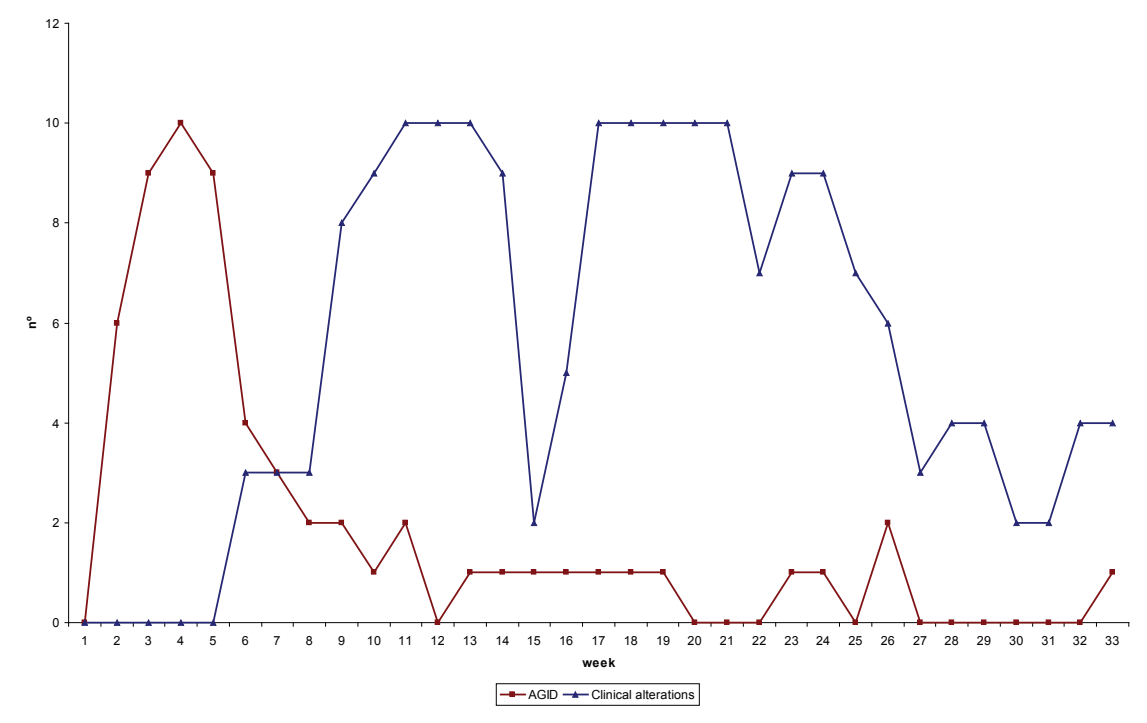

Source: Elaboration of the authors.

\section{Discussion}

Antibody titers started to be detected in the first week after inoculation and were variable, showing fluctuations during the whole period of the study. Similar results were observed in 10 animals inoculated experimentally by intrapreputial route; titers were observed beginning in the $2^{\text {nd }}$ week after inoculation, with some animals showing fluctuating titers (WEBB et al., 1980). According to Plant, Eamens and Seaman, (1986), results were also similar using complement fixation test in Merino rams. The authors observed that titers generally developed earlier in animals that were exposed by intrapreputial route, when compared with other routes of inoculation, corroborating the occurrence of positive results beginning in the first week of the present study.

Clinical changes were not only observed in all animals experimentally inoculated with $B$. ovis REO 198, but also in animals infected naturally. Changes began in the $5^{\text {th }}$ week after inoculation. However, most animals showed clinical changes in the $9^{\text {th }}$ week, followed by periods when changes decreased. Titers remained very high until the $24^{\text {th }}$ week. Similar results were observed in an experiment where all Merino rams showed clinical lesions, lasting for eight weeks, after three weeks of inoculation (WEBB et al., 1980). Changes observed in the acute and chronic phases of the disease varied, and animals returned to normal conditions after some weeks. Other studies also reported that infected animals showing palpable epididymitis frequently became normal at palpation after few weeks (HUGHES; CLAXTON, 1968; RAMOS et al., 1966; BLASCO, 1990b).

B. ovis shedding in semen was observed in cultures of eight ( $80 \%$ ) animals, from three to seven months after inoculation. Lower rates of isolation (24\%) were reported in 25 Merino rams submitted to preputial instillation of $B$. ovis, from which only six $(24 \%)$ animals shed the bacteria five weeks after exposure (LAWS; SIMMONS; LUDFORD, 1972). Intermittent shedding of the microorganism for two or more times was observed in semen of three animals, and in urine of four animals. Changes in the shedding pattern observed in samples of the same animal reinforce the idea that $B$. ovis elimination in semen is intermittent. Intermittent isolation of $B$. 
ovis in semen samples of infected Merino rams was already reported elsewhere (HUGHES; CLAXTON, 1968). In the present study, one ram took up seven months to shed the organism in semen. These results were similar to those reported for 42 infected rams; two of them never shed the bacteria in semen during the 10 months of study, and another animal did not shed it for four months (WORTHINGTON; STEVENSON; DE LISLE, 1985).

Negative serology with excretion of the bacteria in semen was observed in two studies (BULGIN 1990; MARCO et al., 1994), reinforcing the importance of seronegative animals for the epidemiological chain of the disease. Intermittent shedding in urine was observed in seven (70\%) animals, from 15 days to four months, and from seven to eight months. PCR was able to detect $B$. ovis in kidneys and urinary bladders of the animals, confirming the presence of the agent in the urinary system of the rams (data not shown). This fact underscores the importance of urine as a vehicle for the transmission of the disease. The greatest percentage of animals shedding the organism in urine occurred from 15 days to four months after inoculation, and it was observed that one ram shed it only in urine. Several authors showed the importance of this route of transmission, mainly because it leads to the contamination of pastures and water sources (GRILLÓ et al., 1999; QUISPE; RIVERA; ROSADIO, 2002). Results showed that $B$. ovis shedding in semen and urine of infected animals was intermittent, beginning in 15 days of inoculation and continuing during the eight months of the study. This finding underscores the importance of animal excretions as routes of elimination and serology of the animals as potential sources of infection. Intermittent shedding of the bacteria may also complicate diagnosis, once results of microbiological culture may be negative.

After experimental inoculation, antibodies were detected in the $1^{\text {st }}$ week and remained detectable, although in variable rate $(10-20 \%)$, until the $18^{\text {th }}$ week. They then decreased with maximum rates of negative and positive results equal to $20 \%$. On the other hand, clinical signs affected $100 \%$ of the animals, peaking between the $11^{\text {th }}$ and $13^{\text {th }}$ week and between the $16^{\text {th }}$ and $20^{\text {th }}$ week, and remaining at a rate of $10-20 \%$ in the final phase of the study. Development of clinical signs, humoral immune response and elimination of $B$. ovis in urine and semen of animals experimentally inoculated, associated with the natural development of the disease due to casual contact between the group control shows the pathogenicity of this $B$. ovis strain for sheep. This study reinforces the importance of urine as an alternative route for the elimination of Brucella ovis and as an option for the diagnosis of infected animals.

This research demonstrated that infection with B. ovis REO 198 strain in Santa Inês rams from Brazil experimentally infected and naturally retains the characteristics of pathogenicity of PA strains in others breeds.

\section{Acknowledgements}

To FAPESP (Fundação de Amparo a Pesquisa do Estado de São Paulo).

\section{References}

ALTON, G. G.; JONES, L. M.; PIETZ, D. E. Las tecnicas de laboratorio en la brucellosis. World Health Organ Monograph Series, Geneva, v. 55, p. 55-133, 1976.

ALTON, G. G.; JONES, L. M.; ANGUS, R. D.; VERGER, J. M. Techniques for the brucellosis laboratory. Paris: INRA French National Institute for Agricultural Research, 1971. 109 p.

BLASCO, M. J. M. Brucella ovis. In: NIELSEN, K.; DUNCAN, J. R. (Ed.). Animal Brucellosis. Boca Raton: CRC Press, 1990b. p. 351-378.

BLASCO, M. J. M. Brucelosis ovina: epidemiologia, patogenia y cuadro clínico. Zaragoza: Luzáns, 1990a.

BROWN, G. M.; RANGER, C. R.; KELLEY, D. J. Selective media for the isolation of Brucella ovis. Cornell Veterinarian, Ithaca, v. 61, p. 265-280, 1971. 
BULGIN, M. S. Brucella ovis excretion in semen of seronegative, clinically normal breeding rams. Journal of the American Veterinary Medical Association, Schaumburg v. 196, p. 313-315, 1990.

GRILLÓ, M. J.; MARÍN, C. M.; BARBERÁN, M.; BLASCO, J. M. Experimental Brucella ovis infection in pregnant ewes. Veterinary Record, London, v. 144, n. 148, p. 555-558, 1999.

HOMSE, A. C.; CASARO, A. P.; CAMPERO, C. M. Infertilidad em ovejas por B. ovis. Veterinaria Argentina, Buenos Aires, v. 12, n. 114, p. 243-249, 1995.

HUGHES, K. L.; CLAXTON, P. D. Brucella ovis infection. An evaluation of microbiological, serological and clinical methods of diagnosis in the ram. Australian Veterinary Journal, Malden, v. 44, n. 2, p. 41-47, 1968.

LAWS, L.; SIMMONS, G. C.; LUDFORD, C. G. Experimental Brucella ovis infection in rams. Australian Veterinary Journal, Malden, v. 48, n. 6, p. 313-317, 1972.

MANAZZA, J. Brucelosis ovina. Buenos Aires: Instituto Nacional de Tecnologia Agropecuária INTA, 2005. Disponível em: <http://www.inta.gov.ar/balcarce/gsa. htm>. Acesso em: 15 jun. 2007.

MANTEROLA, L.; TEJERO-GARCÉS, A.; FICAPAL, A.; SHOPAYEVA, G.; BLASCO, J. M.; MARIN, C. M.; LÓPEZ-GOÑI, I. Evaluation of a PCR test for the diagnosis of Brucella ovis infection in semen samples from rams. Veterinary Microbiology, Barcelona, v. 92, n. 1-2, p. 65-72, 2003.

MARCO, J.; GONZÁlEZ, L.; CUERVO, L. A.; HEREDIA, F. B.; BARBERAN, M.; MARIN, C.; BLASCO, J. M. Brucella ovis infection in two flocks of sheep. Veterinary Record, London, v. 135, n. 111, p. 254256, 1994.

NAREZ, G. M.; APARICIO, E. D.; ÁllareZ, J. F. M.; ROMERO, F. A.; GÜEMES, F. S. Epidimitis ovina: estudios bacteriológico y serológico. Revista Veterinaria. México, Coyoacán, v. 30, n. 4, p. 329-336, 1999.
PAOLICCHI, F. A.; CASARO, P. A.; GIMENO, E. J.; KORTEBANI, L. G.; MAZZOLLI, A. B. Antisperm response in rams experimentally infected with Brucella ovis. Small Ruminant Research, v. 36, n. 1, p. 7-15, 2000.

PLANT, J. W.; EAMENS, G. J.; SEAMAN, J. T. Serological, bacteriological and pathological changes in rams following different routes of exposure to Brucella ovis. Australian Veterinary Journal, Malden, v. 63, n. 12, p. 409-412, 1986.

QUISPE, R. C. H.; RIVERA, H. G.; ROSADIO, R. A. Cinética de la infección por Brucella ovis en carneros durante una época de empadre. Revista de Investigaciones Veterinárias del Perú, Lima, v. 13, n. 1, p. 61-66, 2002.

RAMOS, A. A.; MIES FILHO, A.; SCHENCK, J. A. P.; VASCONCELlOS, L. D.; PRADO, O. T.; FERNANDES, J. C. T.; BLOBEL, H. Epididimite ovina. Levantamento clínico no Rio Grande do Sul. Pesquisa Agropecuária Brasileira, Brasília, v. 1, p. 211-213, 1966.

WEBB, R. F.; QUINN, C. A.; COCKRAM, F. A.; HUSBAND, A. J. Evaluation of procedures for the diagnosis of Brucella ovis infection in rams. Australian Veterinary Journal, Malden, v. 56, n. 4, p. 172-175, 1980.

WEST, D. M.; WEST, D. M.; STAFFORD, K. J.; ALLEY, M. R.; BADCOE, L. M.; HILBINK, F.; COMPTON, C. W. R. Serological and necropsy findings for rams infected with Brucella ovis which were not identified by the complement fixation test. New Zealand Veterinary Journal, Palmerston North, v. 41, n. 2, p. 82-86, 1993.

WORTHINGTON, R. W.; STEVENSON, B. J.; DE LISLE, G. W. Serology and semen culture for the diagnosis of Brucella ovis infection in chronically infected rams. New Zealand Veterinary Journal, Palmerston North, v. 33, n. 4, p. 84-86, 1985. 